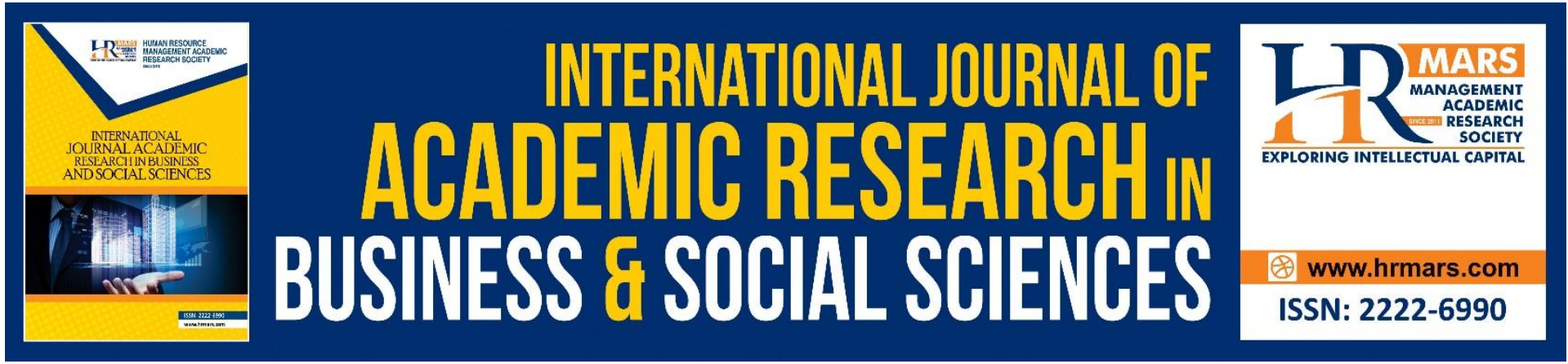

\title{
Identifying Needs For Development of Organic Reaction Teaching Model (ORTM)
}

Abdulmalik Sabitu, Othman Talib, Norizah Abdul Rahman, Nurzatulshima Kamaruddin, Tengku Putri Norishah

To Link this Article: http://dx.doi.org/10.6007/IJARBSS/v10-i12/8064

DOI:10.6007/IJARBSS/v10-i12/8064

Received: 13 October 2020, Revised: 08 November 2020, Accepted: 30 November 2020

Published Online: 16 December 2020

In-Text Citation: (Sabitu et al., 2020)

To Cite this Article: Sabitu, A., Talib, O., Rahman, N. A., Kamaruddin, N., \& Norishah, T. P. (2020). Identifying Needs For Development of Organic Reaction Teaching Model (ORTM). International Journal of Academic Research in Business and Social Sciences, 10(12), 192-209.

Copyright: @ 2020 The Author(s)

Published by Human Resource Management Academic Research Society (www.hrmars.com)

This article is published under the Creative Commons Attribution (CC BY 4.0) license. Anyone may reproduce, distribute, translate and create derivative works of this article (for both commercial and non-commercial purposes), subject to full attribution to the original publication and authors. The full terms of this license may be seen

at: http://creativecommons.org/licences/by/4.0/legalcode

Vol. 10, No. 12, 2020, Pg. 192 - 209

Full Terms \& Conditions of access and use can be found at http://hrmars.com/index.php/pages/detail/publication-ethics 


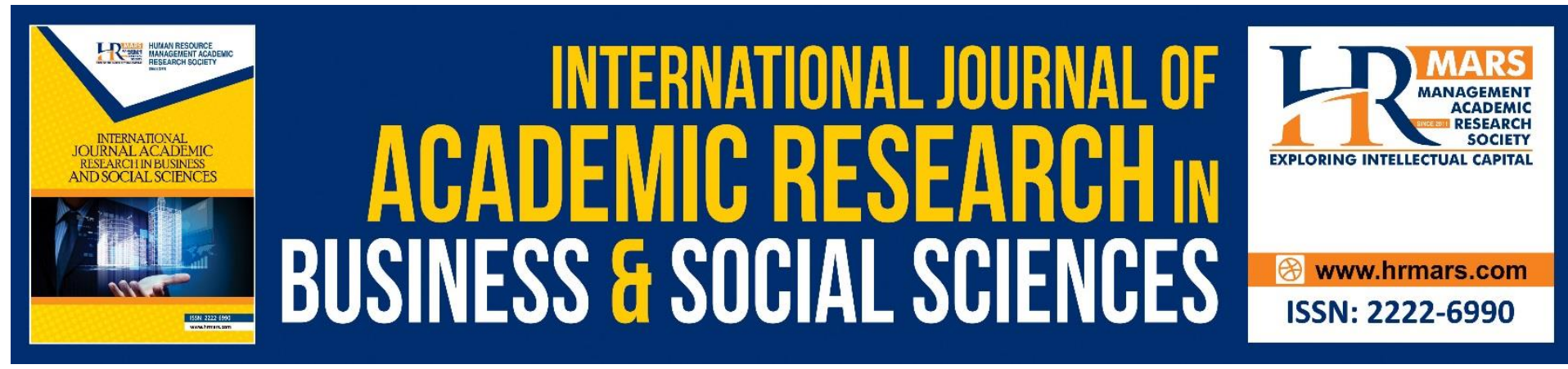

\title{
Identifying Needs For Development of Organic Reaction Teaching Model (ORTM)
}

\section{Abdulmalik Sabitu, Othman Talib, Norizah Abdul Rahman, Nurzatulshima Kamaruddin, Tengku Putri Norishah}

Federal University Dustin-Ma, Katsina State, 821, Nigeria, Faculty of Educational Studies, Universiti Putra Malaysia, 43400, Serdang, Malaysia, Faculty of Science, Universiti Putra Malaysia, 43400, Serdang, Malaysia, Multimedia University, Persiaran Multimedia, 63100

Cyberjaya, Malaysia, Faculty of Educational Studies, Universiti Putra Malaysia, 43400, Serdang

Email: asabitu@fudutsinma.edu.ng, otalib@upm.edu.my, a_norizah@upm.edu.my, tengku.norishah@mmu.edu.my,nz_shima@upm.edu.my

\begin{abstract}
Organic reaction mechanism (ORM) is the step-by-step sequence of reactions which describes the occurrence of chemical changes among organic compounds. The concept has been perceived by many students as being difficult. Mere memorisation of this concept has led to a partial recall of facts and misconceptions that make the concepts more difficult. Identifying the needs for developing organic reaction mechanisms teaching model is an important part of chemistry instruction. This study focuses on the review of studies, especially in the context of students' difficulties and common errors to justify the need for developing alternative model for teaching organic reaction. The study applies the scoping review procedure including identification of research questions, selecting relevant studies, the setting of inclusion and exclusion criteria, and finally charting and data reporting. The scoping review of 15 articles published between 2014 and 2019 indicates indicated that students faced difficulties in learning ORM. Additionally, the studies have identified the common errors of students when learning ORM such as hypervalency, wrong use of arrows, and failure to conserve charges. Finally, the implications for teaching and learning ORM and the need to develop an alternative teaching model was justified.
\end{abstract}

Keywords: Organic Reaction Mechanisms, Scoping Review, Students' Common Errors

\section{Introduction}

Organic Reaction Mechanisms (ORM) is a basic principle in organic chemistry used to explain the synthesis of carbon compounds. The concept is part of a spiral curriculum taught to students from secondary school to university level. ORM concept is important not only in the chemistry education programme but is also integral components of other fields such as agriculture, biology, biochemistry, forestry, and medicine. The principles of organic reaction mechanisms are applied in various industries that are paramount to the economic development of the country, such as petrochemicals, plastics, textile research, food, and 
pharmaceutical sciences. Researchers (Bhattacharyya, 2019; Talib, Othman, \& Tengku Putri Norishah, 2014; Popova \& Bretz, 2018; Zarubica et al., 2012; Darwish et al., 2018) A good understanding of how ORM occurs has been reported to be vital in the synthesis of organic compounds. Othman Talib et al (2014, pp. 530) concluded in their review of the nature of organic chemistry that "understanding the fundamental concepts of ORM is crucial for students before they can learn more advanced topics." Other studies by Anzovino and Lowery Bretz (2015); Bodé, Deng, and Flynn (2019) show that acquiring the skills required to solve synthesis-type problems is the greatest cognitive learning outcome for organic chemistry students. It is, therefore, necessary for students to understand how to draw reasonable organic reaction mechanisms that provide students with the basic knowledge they need to understand before they can progress to more advanced organic chemistry courses.

The arrow pushing technique is the widely used method for teaching ORM (Flynn \& Featherstone, 2017; Flynn \& Ogilvie, 2015; Galloway, Leung, \& Flynn, 2019). The technique requires the use of curved arrows to demonstrate the transfer of a pair of electrons from an electron-rich position to an electron-poor location (Levy, 2008). For example, in the SN1 reaction via an intermediate carbocation in Figure 1, it indicated how the electron movement is shown by a curved arrow.
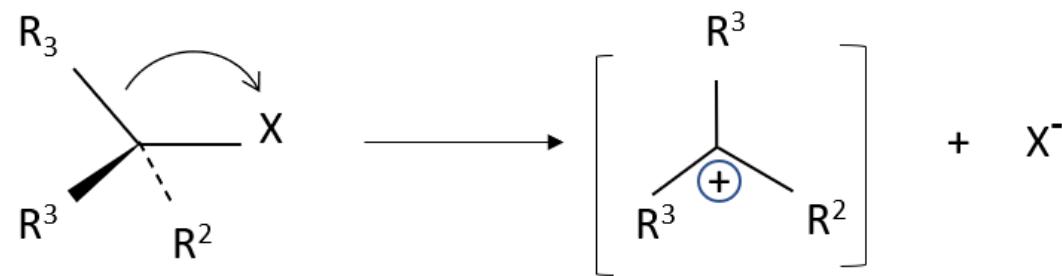

Figure 1: The example of a curved arrow in organic mechanism reaction

The curved arrow with a full head is used in drawing a mechanism to describe the movement of a pair of electrons, as part of the language symbolism that chemists apply to accurately explain the flow of electrons during a reaction. As a symbol, the type of arrow illustrates a specific meaning. For example, the 'arrow-tail' indicates the source of an electron; the donor or bond from which the electron originated while the 'arrow-head' indicates the destination where the electron pair to end up; usually known as the electron acceptor (Bhattacharyya, 2013). The single barb arrow is often used to signify a single electron's movement, while the movement of a pair of electrons is indicated by a double barb arrow. When using the curved arrow mechanism, there are a few more guidelines that students need to obey, such as the direction of arrow movement should start from lone pairs or bonds and end either at an atom or a pair of atoms, the charges should be balanced in any particular step; a bond is formed if electrons are placed between 2 atoms. However, it means the bond is broken when electrons are pushed out of a bond.

Other special terminologies necessary for effective use of arrow pushing strategy are the alphanumeric characters, signs, and shorten words to make reactions explicit, such as 'alpha' carbon (Figure2) and 'beta' elimination. These also include dots to indicate lone pairs or nonbonding electrons and lines to show a covalent bond. The proper use of these special terminologies is an essential skill to master as it would help students understand how a reaction transpires. However, many students perceive this symbolic language as an additional mental 'load' that intensifies the abstractness of organic reaction mechanisms which leads to increased confusion (Meyer \& Land, 2005; Talib et al., 2014). 


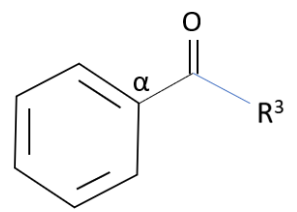

Figure 2: Alpha carbon is a carbon next to a functional group (carbonyl)

While textbooks are explaining the techniques for drawing organic reaction mechanisms, the ability to grasp and recall the bewildering sequence of organic reactions is still difficult, such as 'The Art of Writing Reasonable Organic Reaction Mechanisms,' authored by Grossman (2003). This is due to the carbon catenation properties that allow it to shape a large number of compounds that cannot be easily understood in the shape of straight, branched, cyclic, alicyclic, saturated, and unsaturated (Talib et al, 2012). As a result, scholars are increasingly interested in developing the teaching and learning methods of organic reaction mechanisms (Bhattacharyya, 2013; Arellano \& Towns, 2014). The existing model of representation used by teachers is unable to describe the actual processes involved in organic reactions directly to students (Flynn \& Featherstone, 2017). Similarly, it is difficult for students to move their thoughts easily from one idea to another and link them, such as from the submicro level to the macro and symbolic levels (Treagust, Chittleborough \& Mamiala, 2003). Phrases such as macroscopic, microscopic, and symbolic levels are used for these levels of representation (Ben-Zvi, Eylon, \& Silberstein, 1987); a chemical universe of macroscopic, molecular, and symbolic (Bodner, 1992); microchemistry, sub-microchemistry, and representational chemistry (Johnstone, 1993).

Previous studies have highlighted the causes of difficulties in learning mechanisms of organic reaction, such as the abstract nature of concepts, overload of the working memory space of students, extensive use of new vocabulary, psychological fear of chemistry, and lack of motivation, and interest among students (Al-Balushi \& Al-Hajri, 2014; Bongers, Northoff, \& Flynn, 2019; Caspari, Kranz, \& Graulich, 2018; Ferguson \& Bodner, 2008). In several cases, loss of interest could be associated with bad experiences such as low grades and fear of laboratory accidents. The teachers' incompetence due to insufficient expertise in the content knowledge as well as unpreparedness in planning for their lessons is one of the prominent causes of the poor performance of the students. (Hanson \& Acquah, 2014). The extensive use of new vocabulary in the form of language symbolism and numerous representations to describe several phenomena of interest that include simplified depictions of certain sub microscopic particles that cannot be seen with the naked eye is another cause of student difficulty in learning organic reaction mechanisms (Tsaparlis, 2009). The artistic depiction of these abstract concepts, however, requires students to acquire language skills and the ability to interpret visual representation to have a realistic understanding of reaction mechanisms. For students, these tasks are very difficult since they need to consider each representation unit in isolation, then define and construct the meaning of the relationships between these representation units through a process called coherence formulation (Chittleborough \& Treagust, 2007).

Further research on students' challenges in learning organic reaction mechanisms has identified some of the common errors students make whilst drawing organic reactions mechanisms including inappropriate arrow positioning and direction, arrow shortage, hypervalency, mixed media errors, and charges conservation failure (Arellano and Towns, 2014; Grossman, 2003; Webber and Flynn, 2018; Weinrich and Sevian, 2017). Students often 
struggle to follow experts' way of thinking; this arduous effort could be an obstacle towards applying their prior knowledge and understanding new concepts. One of the conclusions made by Arellano and Towns (2014) is students are often applying rules they have learned from a particular example to another example in a question because the two examples are similarly based upon the surface features of the molecules compared. These students incorrectly generalize the rules which they apply to other questions. As a result, they tend to produce incorrect answers. The frequent instances of errors made by students serve as a wake-up call for a study to strategize on a method that would guide students to be aware of their errors to overcome the consequences of repeating these errors in the future. Looking from this perspective, the scoping review has carried out an intensive overview of related research that has linked teaching and learning of organic reaction mechanisms with the causes of difficulties and students' common errors.

\section{Objective of the Study}

This study focuses on the review of past studies, especially in the context of students' difficulties and common errors to justify the need for developing alternative model for teaching organic reactions from the perspectives of scholars in chemistry and chemistry education. The was intended to address the following specific objectives:

i. To identify the causes of difficulties faced by students in learning organic reaction mechanisms.

ii. To identify students' common errors in solving organic reaction mechanisms task.

iii. To examine the variables studies in the past literature of organic reaction mechanism

iv. To identify the limitation of the research conducted on organic reaction mechanisms

\section{Research Questions}

This study focuses on the past studies on the organic reaction mechanisms, especially in the context of the causes of difficulties and students' common errors. To achieve that, a significant number of literatures were captured, and the following research questions were posed to guide the research that will encompass a significant number of references in line with the phenomenon:

i. What are the causes of difficulties students faced in learning organic reaction mechanisms?

ii. What are the students' common errors in writing organic reaction mechanisms?

iii. What are the educational outcomes evolving from the research on organic reaction mechanisms?

iv. What limitations are outlined from the studies in organic reaction mechanisms reviewed?

\section{Methodology}

The scoping review method adopted in this study was underpinned by the procedure outlined by Arksey and O'Malley (2005); García-Moya et al., (2019) which include the identification of research questions and relevant studies, the description of inclusion and exclusion criteria, and the charting and reporting of the data in line with the research objectives. These five stages were used to review articles about students' common errors in writing organic reaction mechanisms and the strategies used by chemistry teachers to teach the ORM concept as follows: 
The 'organic reaction mechanisms' concept is the only search string used for the review to reach a diverse collection of literature. Many papers from open-access peerreviewed journals were successfully captured by this effort via the Mendeley electronic database. The researchers used the Mendeley database because of its flexibility that enables users to use filtering options such as title, year, author, and publication. These options make it easier for the researchers to use the inclusion and exclusion criteria for the selection of relevant articles. The variables for both inclusion and exclusion criteria were determined after several studies are examined and analysed. Table 1 summarised the inclusion and exclusion criteria.

Table 1 Inclusion and Exclusion Criteria

\begin{tabular}{lll}
\hline Criteria & Inclusion & Exclusion \\
\hline Time & Last 6 years (2014- 2019) & Studies outside these dates. \\
Literature focus & $\begin{array}{l}\text { Studies related specifically to organic } \\
\text { reaction mechanisms (e.g., students' reaction mechanisms } \\
\text { strength, challenges, errors, } \\
\text { achievement, and so on) } \\
\text { Students at the undergraduate level }\end{array}$ & $\begin{array}{l}\text { Studies related to high } \\
\text { school and postgraduate }\end{array}$ \\
& & $\begin{array}{l}\text { students } \\
\text { sample }\end{array}$
\end{tabular}

Based on the five steps of the scoping review, a structured extraction form was designed which compiled the demographic data and features of articles to reflect the methodological rigor of the articles examined. Fifteen papers (15) were found to have met the inclusion criteria. The article selection was based on the model of PRISMA (Moher, Liberati, Tetzlaff, \& Altman, 2009). The article selection process is shown step by step, as seen in Figure 3.

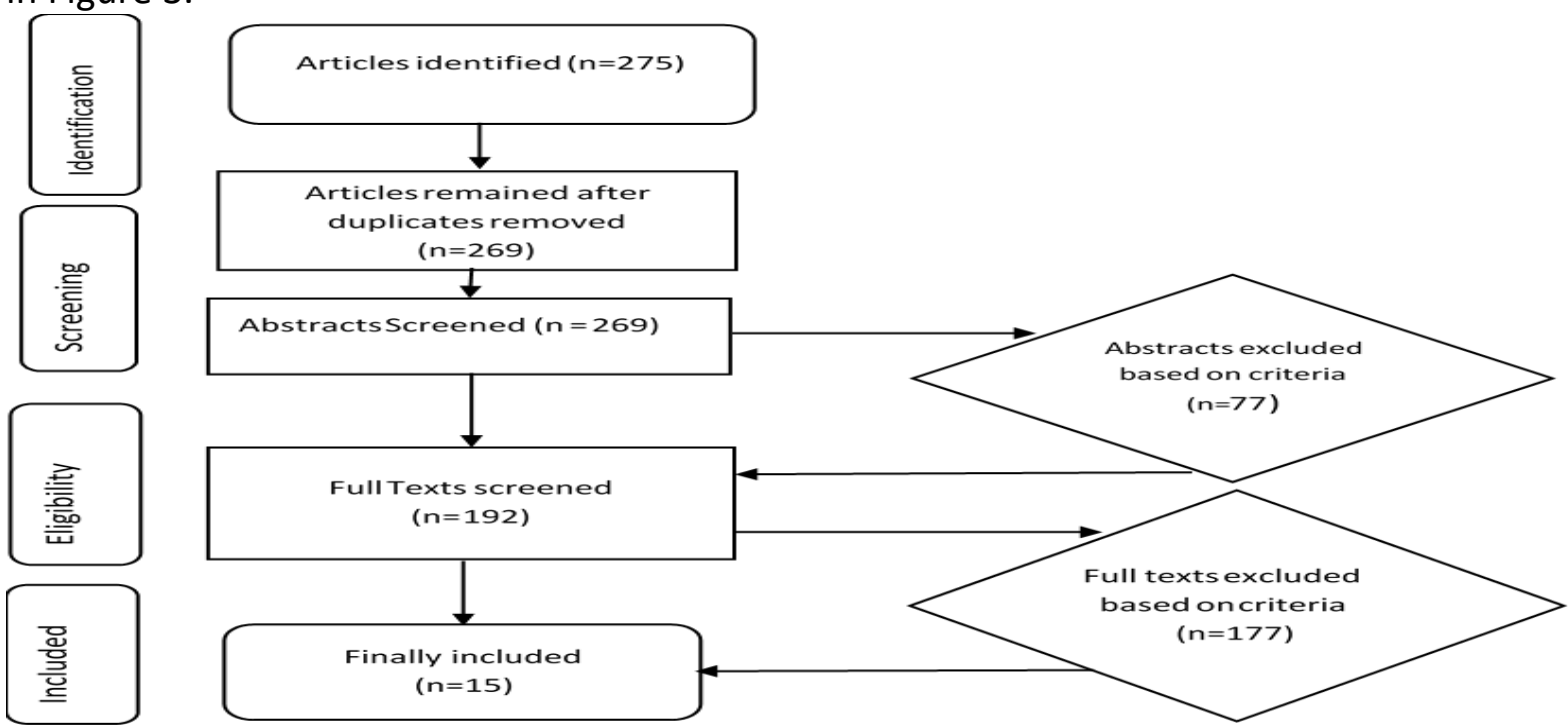

Figure 3 Inclusion and Exclusion process 


\section{Charting the Data}

Data charting is a technique for synthesizing and analysing qualitative data by arranging materials according to the main principles and themes of the research phenomena (Rasheed, Younas, \& Sundus, 2019). This process is considered as the data extraction process in a systematic review. In this study, summaries are developed for each article that satisfied the inclusion criteria, including author(s), year of publication, study location, sample, research issue, methodology, major findings, limitations, and suggestions. Table 2 depicted a summary of these criteria that were concluded from the included studies.

Table 2 Studies Included in the Scoping Review

\begin{tabular}{|c|c|c|c|c|c|}
\hline Author & $\begin{array}{l}\text { 1. Othman } \\
\text { Talib, Azraai } \\
\text { Othman, \& } \\
\text { Tengku Putri } \\
\text { Norishah } \\
\text { (2014) }\end{array}$ & $\begin{array}{l}2 . \quad \text { Bodé, } \\
\text { Deng \& Flynn } \\
\text { (2019) }\end{array}$ & $\begin{array}{l}\text { 3. O'Dwyer \& } \\
\text { Childs (2015) }\end{array}$ & $\begin{array}{l}\text { 4. Bodé \& } \\
\text { Flynn }(2016)\end{array}$ & $\begin{array}{l}\text { 5. Cruz-Ramírez } \\
\text { De Arellano, \& } \\
\text { Towns (2014) }\end{array}$ \\
\hline Country & Malaysia & Canada & Ireland & Canada & United States \\
\hline Sample & $\begin{array}{l}92 \text { under- } \\
\text { graduate } \\
\text { students. }\end{array}$ & $\begin{array}{l}400 \\
\text { university } \\
\text { students. }\end{array}$ & $\begin{array}{l}204 \text { students } \\
\text { and } 6 \\
\text { chemistry } \\
\text { teachers. }\end{array}$ & $\begin{array}{l}700 \text { second- } \\
\text { year } \\
\text { undergraduate } \\
\text { students. }\end{array}$ & $\begin{array}{l}22 \text { under-graduate } \\
\text { students. }\end{array}$ \\
\hline Issue & $\begin{array}{l}\text { The } \\
\text { interactive } \\
\text { multimedia } \\
\text { mobile } \\
\text { learning } \\
\text { application } \\
\text { for teaching } \\
\text { ORM. }\end{array}$ & $\begin{array}{l}\text { Scientific } \\
\text { arguments in } \\
\text { organic } \\
\text { reaction } \\
\text { mechanisms. }\end{array}$ & $\begin{array}{l}\text { Students' } \\
\text { interests and } \\
\text { attitudes } \\
\text { towards } \\
\text { organic } \\
\text { chemistry. }\end{array}$ & $\begin{array}{l}\text { Problem- } \\
\text { solving } \\
\text { strategies and } \\
\text { models of } \\
\text { teaching. }\end{array}$ & $\begin{array}{l}\text { Students' } \\
\text { understanding of } \\
\text { alkyl halide } \\
\text { reactions }\end{array}$ \\
\hline Method & $\begin{array}{l}\text { Quasi- } \\
\text { experimental. }\end{array}$ & $\begin{array}{l}\text { Qualitative } \\
\text { Coding. }\end{array}$ & $\begin{array}{l}\text { Quasi- } \\
\text { experimental. }\end{array}$ & $\begin{array}{l}\text { Qualitative } \\
\text { open coding. }\end{array}$ & Qualitative. \\
\hline Result & $\begin{array}{l}\text { Attitudes of } \\
\text { students } \\
\text { toward ORM } \\
\text { were positive } \\
\text { and their test } \\
\text { scores have } \\
\text { improved. }\end{array}$ & $\begin{array}{l}\text { Students } \\
\text { justify their } \\
\text { answers by } \\
\text { providing } \\
\text { cause-and- } \\
\text { effect } \\
\text { relationships. }\end{array}$ & $\begin{array}{l}\text { Students' } \\
\text { interests and } \\
\text { attitudes } \\
\text { towards the } \\
\text { understanding } \\
\text { of organic } \\
\text { chemistry } \\
\text { improved. }\end{array}$ & $\begin{array}{l}\text { Students } \\
\text { revealed many } \\
\text { strategies in } \\
\text { answering the } \\
\text { ORM task. }\end{array}$ & $\begin{array}{l}\text { Shows incorrect } \\
\text { understanding of } \\
\text { classifying } \\
\text { substances as } \\
\text { bases and } \\
\text { nucleophiles. }\end{array}$ \\
\hline Limitation & $\begin{array}{l}\text { No limitation } \\
\text { was } \\
\text { recognized. }\end{array}$ & $\begin{array}{l}\text { Focused on } \\
\text { only } \\
\text { unimolecular } \\
\text { substitution } \\
\text { reactions. }\end{array}$ & $\begin{array}{l}\text { It was difficult } \\
\text { to determine } \\
\text { the one key } \\
\text { element that } \\
\text { has } \\
\text { contributed to } \\
\text { the project's } \\
\text { success. }\end{array}$ & $\begin{array}{l}\text { Could only } \\
\text { clearly analyse } \\
\text { the } \\
\text { information } \\
\text { retrieved from } \\
\text { students. }\end{array}$ & $\begin{array}{l}\text { The study is } \\
\text { limited to only } \\
\text { alkyl halide } \\
\text { reactions. }\end{array}$ \\
\hline
\end{tabular}




\begin{tabular}{|c|c|c|c|c|c|}
\hline Suggestion & $\begin{array}{l}\text { Development } \\
\text { of mobile } \\
\text { applications } \\
\text { in line with } \\
\text { the current } \\
\text { pedagogical } \\
\text { approaches. }\end{array}$ & $\begin{array}{l}\text { Development } \\
\text { of students' } \\
\text { argument } \\
\text { skills in a } \\
\text { variety of } \\
\text { contexts. }\end{array}$ & $\begin{array}{l}\text { Encourage the } \\
\text { use of } \\
\text { evidence- } \\
\text { based best } \\
\text { practices in } \\
\text { high school } \\
\text { chemistry } \\
\text { classes. }\end{array}$ & $\begin{array}{l}\text { Compare the } \\
\text { effectiveness } \\
\text { of various } \\
\text { learning } \\
\text { strategies }\end{array}$ & $\begin{array}{l}\text { Development of a } \\
\text { diagnostic } \\
\text { instrument for } \\
\text { alkyl halide } \\
\text { reactions. }\end{array}$ \\
\hline
\end{tabular}

Table 2 Continued

\begin{tabular}{|c|c|c|c|c|c|}
\hline Author & $\begin{array}{lr}6 . & \text { Caspari, } \\
\text { Kranz } & \& \\
\text { Graulich } & (2018)\end{array}$ & $\begin{array}{l}\text { 7. Weinrich } \\
\& \quad \text { Sevian } \\
(2017)\end{array}$ & $\begin{array}{l}8 . \\
\text { Bhattacharyya } \\
(2013)\end{array}$ & $\begin{array}{l}\text { 9. Bongers, } \\
\text { Northoff \& } \\
\text { Flynn (2019) }\end{array}$ & $\begin{array}{l}10 . \\
\text { Bhattacharyya } \\
\text { (2019) }\end{array}$ \\
\hline Country & Germany & United States & United States & Canada & United States \\
\hline Sample & $\begin{array}{l}20 \text { under- } \\
\text { graduate } \\
\text { students. }\end{array}$ & $\begin{array}{l}20 \text { under- } \\
\text { graduate } \\
\text { students. }\end{array}$ & $\begin{array}{l}44 \text { organic } \\
\text { chemistry } \\
\text { professors. }\end{array}$ & $\begin{array}{l}7 \text { under- } \\
\text { graduate } \\
\text { students. }\end{array}$ & A review article. \\
\hline Issue & $\begin{array}{l}\text { Reasoning } \\
\text { through the lens } \\
\text { of the } \\
\text { mechanistic } \\
\text { framework }\end{array}$ & $\begin{array}{l}\text { Capturing } \\
\text { student's } \\
\text { abstraction } \\
\text { in solving } \\
\text { ORM } \\
\text { problems. }\end{array}$ & $\begin{array}{l}\text { Mechanistic } \\
\text { reasoning } \\
\text { using electron- } \\
\text { pushing } \\
\text { formalisms. }\end{array}$ & $\begin{array}{l}\text { The } \\
\text { character of } \\
\text { mental } \\
\text { models. }\end{array}$ & $\begin{array}{l}\text { The concepts of } \\
\text { unanalyzed } \\
\text { chunks and } \\
\text { syntacticized. }\end{array}$ \\
\hline Method & $\begin{array}{l}\text { Qualitative } \\
\text { study. }\end{array}$ & $\begin{array}{l}\text { Qualitative } \\
\text { study. }\end{array}$ & Survey & Qualitative & Review \\
\hline Result & $\begin{array}{l}\text { There is a weak } \\
\text { connection } \\
\text { between the } \\
\text { reasoning about } \\
\text { the structural } \\
\text { account and the } \\
\text { energetic } \\
\text { representation. }\end{array}$ & $\begin{array}{l}\text { Students } \\
\text { who } \\
\text { proposed } \\
\text { plausible } \\
\text { solutions } \\
\text { using both } \\
\text { strict and } \\
\text { partial } \\
\text { matching. }\end{array}$ & $\begin{array}{l}\text { Electron- } \\
\text { pushing } \\
\text { formalism } \\
\text { (EPF) is a } \\
\text { mechanism } \\
\text { primarily an } \\
\text { explanatory } \\
\text { and predictive } \\
\text { tool. }\end{array}$ & $\begin{array}{l}\text { Students } \\
\text { relied on a } \\
\text { combination } \\
\text { of static and } \\
\text { dynamic } \\
\text { working } \\
\text { mental } \\
\text { models } \\
\text { depending } \\
\text { on the task. }\end{array}$ & $\begin{array}{l}\text { Students } \\
\text { internalized } \\
\text { entire pathways } \\
\text { as single units of } \\
\text { information. }\end{array}$ \\
\hline Limitation & $\begin{array}{l}\text { The researcher } \\
\text { was only able to } \\
\text { analyse } \\
\text { students' verbal } \\
\text { answers during } \\
\text { the interviews. }\end{array}$ & $\begin{array}{l}\text { No } \\
\text { limitations } \\
\text { were } \\
\text { recognized. }\end{array}$ & $\begin{array}{l}\text { No limitation is } \\
\text { recognized. }\end{array}$ & $\begin{array}{l}\text { A limited } \\
\text { sample was } \\
\text { used. }\end{array}$ & $\begin{array}{l}\text { No limitation is } \\
\text { recognized. }\end{array}$ \\
\hline Suggestion & $\begin{array}{l}\text { Development of } \\
\text { a framework for } \\
\text { clearer } \\
\text { communication }\end{array}$ & $\begin{array}{l}\text { Development } \\
\text { of an } \\
\text { instructor's } \\
\text { assessment } \\
\text { practices in a }\end{array}$ & $\begin{array}{l}\text { Mechanistic } \\
\text { reasonings } \\
\text { should be } \\
\text { made clear to } \\
\text { students to be }\end{array}$ & $\begin{array}{l}\text { More } \\
\text { research on } \\
\text { the use of } \\
\text { working } \\
\text { mental }\end{array}$ & $\begin{array}{l}\text { A significant } \\
\text { portion of } \\
\text { instruction should } \\
\text { emphasize } \\
\text { helping students }\end{array}$ \\
\hline
\end{tabular}




\begin{tabular}{|l|l|l|l|l|l|}
\hline & $\begin{array}{l}\text { way that } \\
\text { would build } \\
\text { students' } \\
\text { abstraction } \\
\text { capacity. }\end{array}$ & $\begin{array}{l}\text { aware of the } \\
\text { uses of EPF. }\end{array}$ & $\begin{array}{l}\text { models for } \\
\text { teaching } \\
\text { reaction } \\
\text { mechanisms. }\end{array}$ & $\begin{array}{l}\text { to syntacticize } \\
\text { mechanisms. }\end{array}$ \\
\hline
\end{tabular}

Table 2 Continued

\begin{tabular}{|c|c|c|c|c|c|}
\hline Author & $\begin{array}{l}\text { 11. Galloway, } \\
\text { Leung \& Flynn } \\
(2019)\end{array}$ & $\begin{array}{l}\text { 12. } \\
\text { Anzovino } \\
\text { Bretz, (2015) }\end{array}$ & $\begin{array}{l}\text { 13. Popova } \\
\& \quad \text { Bretz } \\
(2018)\end{array}$ & $\begin{array}{l}\text { 14. Flynn \& } \\
\text { Featherstone } \\
(2017)\end{array}$ & $\begin{array}{l}\text { 15. Webber \& Flynn } \\
\text { (2018) }\end{array}$ \\
\hline Country & Canada & United States & $\begin{array}{l}\text { United } \\
\text { States }\end{array}$ & Canada & Canada \\
\hline Sample & $\begin{array}{l}16 \text { under- } \\
\text { graduate } \\
\text { students. }\end{array}$ & $\begin{array}{l}11 \text { under- } \\
\text { graduate } \\
\text { students. }\end{array}$ & $\begin{array}{l}36 \text { under- } \\
\text { graduate } \\
\text { students. }\end{array}$ & $\begin{array}{l}399 \quad \text { under- } \\
\text { graduate } \\
\text { students. }\end{array}$ & $\begin{array}{l}11 \text { under-graduate } \\
\text { students. }\end{array}$ \\
\hline Issue & $\begin{array}{l}\text { Reaction } \\
\text { patterns for } \\
\text { mechanistic } \\
\text { thinking }\end{array}$ & $\begin{array}{l}\text { Ideas about } \\
\text { nucleophiles } \\
\text { and } \\
\text { electrophiles. }\end{array}$ & $\begin{array}{l}\text { Coherence } \\
\text { formation } \\
\text { of reactions } \\
\text { and } \\
\text { coordinate } \\
\text { diagrams. }\end{array}$ & $\begin{array}{l}\text { Students' } \\
\text { strength and } \\
\text { errors in } \\
\text { understanding } \\
\text { reaction } \\
\text { mechanisms }\end{array}$ & $\begin{array}{lr}\text { Connecting } & \\
\text { structures } & \text { to } \\
\text { function } & \text { and } \\
\text { language } & \text { of } \\
\text { chemistry. } & \end{array}$ \\
\hline Method & Mixed method & Qualitative & $\begin{array}{l}\text { Qualitative } \\
\text { study }\end{array}$ & $\begin{array}{l}\text { Qualitative } \\
\text { study }\end{array}$ & Qualitative study \\
\hline Result & $\begin{array}{l}\text { Mechanistic } \\
\text { reasoning is } \\
\text { needed to } \\
\text { explicitly } \\
\text { understand the } \\
\text { patterns of } \\
\text { organic } \\
\text { reaction. }\end{array}$ & $\begin{array}{l}\text { Nucleophiles } \\
\text { and } \\
\text { Electrophiles } \\
\text { are } \\
\text { prerequisites } \\
\text { to learning } \\
\text { mechanisms. }\end{array}$ & $\begin{array}{l}\text { Revealed } \\
\text { incorrect } \\
\text { ideas on the } \\
\text { meaning of } \\
\text { reactions } \\
\text { and } \\
\text { coordinate } \\
\text { diagrams. }\end{array}$ & $\begin{array}{l}\text { Revealed little } \\
\text { evidence of } \\
\text { students' } \\
\text { strategies } \\
\text { such as } \\
\text { mapping and } \\
\text { expanding but } \\
\text { found errors } \\
\text { in ORM. }\end{array}$ & $\begin{array}{l}\text { Students struggled } \\
\text { with acronyms in } \\
\text { visualizing } \\
\text { structures. }\end{array}$ \\
\hline Limitation & $\begin{array}{l}\text { No limitation is } \\
\text { recognized. }\end{array}$ & $\begin{array}{l}\text { The study is } \\
\text { limited to } \\
\text { nucleophiles } \\
\text { and } \\
\text { electrophiles. }\end{array}$ & $\begin{array}{l}\text { A limited } \\
\text { subject was } \\
\text { used. }\end{array}$ & $\begin{array}{l}\text { Did not } \\
\text { measure a } \\
\text { student's } \\
\text { conceptual } \\
\text { understanding } \\
\text { of reaction } \\
\text { mechanisms. }\end{array}$ & $\begin{array}{l}\text { A limited subject } \\
\text { was used. }\end{array}$ \\
\hline Suggestion & $\begin{array}{l}\text { Provided } \\
\text { information to } \\
\text { students to } \\
\text { look for } \\
\text { similarities } \\
\text { among } \\
\text { reactions using } \\
\text { card sort task. }\end{array}$ & $\begin{array}{l}\text { Crosscutting } \\
\text { nucleophilic } \\
\text { and } \\
\text { electrophilic } \\
\text { concepts } \\
\text { before } \\
\text { mechanisms. }\end{array}$ & $\begin{array}{l}\text { More } \\
\text { research on } \\
\text { techniques } \\
\text { to reduce } \\
\text { the load on } \\
\text { the working } \\
\text { memory. }\end{array}$ & $\begin{array}{l}\text { Teaching } \\
\text { language } \\
\text { symbolisms } \\
\text { before } \\
\text { reaction. }\end{array}$ & $\begin{array}{l}\text { Drawing out } \\
\text { structures, not just } \\
\text { acronyms, should } \\
\text { be part of } \\
\text { assessments. }\end{array}$ \\
\hline
\end{tabular}




\section{Findings}

At this stage, the researcher summarises and presents the report of the findings in line with the procedure followed. The findings are reported logically and more easily to aid the understanding of the issues raised and discussions were made in line with the research questions. This scoping study reviewed 15 published studies conducted in different countries. Out of which six studies were conducted in the United States, six in Canada, one in Germany, one in Ireland, and one in Malaysia. Research questions were answered in this section of the study by explaining the relevant studies included in the scoping review. The chosen studies addressed the causes of difficulties encountered by students in interpreting organic reaction mechanisms, the frequent errors of the students, academic performance, and shortcomings evolving from teaching and learning organic reaction mechanisms.

Question one: What are the sources of difficulties encountered by students in studying organic reaction?

Findings from several papers in this scoping review revealed the causes of difficulties facing students in learning mechanisms of organic reaction, as seen in Table 3.

Table 3 Causes of Students Difficulties in Learning ORM

\begin{tabular}{|c|c|c|c|c|c|c|}
\hline $\begin{array}{l}\text { Study } \\
\text { Number }\end{array}$ & $\begin{array}{l}\text { low interest } \\
\text { and } \\
\text { misconception }\end{array}$ & $\begin{array}{l}\text { Low } \\
\text { cognitive } \\
\text { ability }\end{array}$ & $\begin{array}{l}\text { Abstract } \\
\text { nature of } \\
\text { the } \\
\text { concepts }\end{array}$ & $\begin{array}{l}\text { Heavy } \\
\text { content }\end{array}$ & $\begin{array}{l}\text { Extensive } \\
\text { use of new } \\
\text { vocabulary }\end{array}$ & $\begin{array}{l}\text { Poor } \\
\text { knowledge } \\
\text { of the basic } \\
\text { concepts }\end{array}$ \\
\hline $1,3,2$ & $\checkmark$ & & & & & \\
\hline $11,14,15$ & & $\checkmark$ & & & & \\
\hline $6,8,11,13$ & & & $\vee$ & & & \\
\hline $8,10,14$ & & & & $\checkmark$ & & \\
\hline $3,2,5,12$ & & & & & $\checkmark$ & \\
\hline 13 & & & & & & \\
\hline $8,12,3,15$ & & & & & & $\checkmark$ \\
\hline
\end{tabular}

From the outcomes of different studies, Table 3 shows the sources of student problems in studying organic reaction mechanisms. Several causes have been attributed to the difficulties encountered by students in studying organic reaction mechanisms. First, it is widely acknowledged that the abstract nature of science subjects is considered one of the reasons for students' difficulty to understand organic reaction mechanisms which are generally complex and dynamic. The ORM concepts comprise many silent features that cannot be explicitly seen. As an example, the distinctive ability of carbon to create countless compound possibilities as well as trigger different types of reactions may cause students' working memory space to be overloaded with extraneous information.

Moreover, students have shown that they are not interested in organic chemistry when they did not exhibit any sense of curiosity or express concern about the subject which was not successful in capturing students' attention. Hence, students' lack of interest in organic chemistry is directly linked to their misconception of the concepts of organic reaction mechanisms which is regarded as the most crucial concept for understanding advanced organic reactions (Ferguson \& Bodner, 2008). To address this issue, scholars have endeavoured to simplify the learning of organic reaction mechanisms to attract students' attention and increase their interest in organic chemistry. It has been widely reported that new vocabulary has been used to explain organic reaction mechanisms through language 
symbolisms. This unique system of representation engages alphanumeric characters, Greek symbols, lines, dots, a curved arrow, and/or geometric shapes to explain what happens during the reactions of organic compounds (Bhattacharyya, 2019; Flynn \& Featherstone, 2017). Nonetheless, the use of language symbolisms to introduce special vocabularies in teaching organic reaction mechanisms is considered controversial. As perceived by many researchers, the extensive use of new vocabulary resulted in the burdening of additional mental 'load' onto students (Bongers, Northoff, \& Flynn, 2019). Another study on how students solve an organic reaction mechanisms task has revealed that students who tried to memorize whole reaction mechanisms as an indivisible unit of information often become confused and make a lot of errors. Whereas students who can conceptualize mechanisms as a sequence of distinct stages are more likely to solve the most difficult organic reaction mechanisms tasks (Bhattacharyya, 2019). Therefore, it is crucial to emphasize the necessity to assist students in learning how to break down reaction mechanisms into meaningful constituents.

This process is referred to as the concept of syntacticization that is commonly used in second-language acquisition (Tode, 2003). In language expression, the syntacticization process involves analysing bits of information by separating the information into meaningful units. Applying this process in learning organic reaction mechanisms would explicitly explain the decomposition of compounds into their constituent radicals or ions, expanding students' chemical vocabulary, and helping them to learn the laws that govern reactions (Bhattacharyya, 2019; Bodé, Deng, \& Flynn, 2019). Similarly, when organic compounds are broken down, the smaller bits will be used generatively by the student to construct plausible reaction mechanisms.

Question Two: What are the common errors students make in writing organic reaction?

In some of the papers analysed in this report, some of the common errors students make in writing organic reactions have been captured. The common errors in organic reaction mechanisms as illustrated in the papers examined are shown in Table 4. Most of the reported errors are procedural and systematic and can be mapped to the causes mentioned in Table 3 .

Table 4 Students' Common Errors in ORM Identified in the Studies

\begin{tabular}{lllllll}
\hline $\begin{array}{l}\text { Study } \\
\text { Number }\end{array}$ & $\begin{array}{l}\text { hyper } \\
\text { valency }\end{array}$ & $\begin{array}{l}\text { charges } \\
\text { conservation } \\
\text { failure }\end{array}$ & $\begin{array}{l}\text { Mixed } \\
\text { Media } \\
\text { Errors }\end{array}$ & $\begin{array}{l}\text { Wrong } \\
\text { use of } \\
\text { arrow }\end{array}$ & $\begin{array}{l}\text { Wrong } \\
\text { of } \\
\text { nucleophiles } \\
\text { and } \\
\text { electrophiles }\end{array}$ & $\begin{array}{l}\text { Drawing } \\
\text { wrong } \\
\text { structures }\end{array}$ \\
\hline $\begin{array}{l}1,3,4 \\
9,2\end{array}$ & $\checkmark$ & & & \\
$6,7,811$, & $\checkmark$ & & & & \\
13 & & & & & \\
$8,10,14$ & & & & & \\
$2,5,12$ & & & & & \\
3,15 & & & & & \\
\hline
\end{tabular}

Poor knowledge of fundamental principles such as the atomic structure of atoms and the octet rule, for example, contributes to hypervalent errors. This means that since the sources of errors associated with a task are known, they may be used as examples of errors when teaching a particular technique to increase the success of students. Hence, there is a need to focus on the basic organic chemistry concepts for a deeper understanding of organic 
reaction mechanisms. Thus, selecting basic organic chemistry concepts will transform students' ability to learn and comprehend the complex organic reaction mechanisms through minimising students' common errors. Therefore, re-orienting the use of arrow pushing formalisms by teaching symbolic language to the students before introducing the reactions is crucial.

Similarly, in the teaching of organic reaction mechanisms, teachers should define and apply threshold concepts, and not consider those principles as merely an element of the previous experience of students, which is a common practice of many chemistry teachers. Threshold concepts were defined by Meyer and Land (2005) as 'cognitive portals' to new and previously inaccessible ways of studying a certain subject field. These principles were defined as transformative, egalitarian, immutable, and problematic ideas that open the door in a discipline to highly intelligent thoughts. Talanquer (2011) therefore believes that the mastering of threshold concepts in organic chemistry involves the creation and deconstruction of various cognitive components, including implicit structures that restrict the thoughts of students about chemical compounds and the mechanism of chemical reactions. Inorganic reaction mechanisms, terms such as nucleophiles, electrophiles, atomic structure, Lewis acid and base, chemical bonding, and language symbolisms are often included in defining desirable learning goals, but also to attract students' attention to fundamental theories whose interpretation is likely to require significant conceptual change for effective learning of organic reaction mechanisms.

Question Three: What are the educational outcomes evolving from organic chemistry researchers?

The findings of the scoping review showed several studies that demonstrate students 'progress in understanding organic reaction mechanisms in various dimensions of an instructional outcome, as in Table 5. The results indicate that organic reaction mechanisms are a complex concept which at the higher level of the cognitive learning domains. This is proven from the findings of the studies reviewed which had indicated that variables of higher order thinking skills such as mechanistic reasoning and language symbolisms dominated skills used by students to achieve the performance outcomes measured. The limited studies on students' attitude, interest, and achievement in ORM have so far failed to report what students truly need to understand the organic reaction mechanisms concepts for overcoming common errors.

Table 5 Educational Outcomes Arising from ORM Studies

\begin{tabular}{ll}
\hline Educational Outcome & Study Number \\
\hline Attitude & 1,3 \\
Interest & 2,3 \\
Academic achievement & 1, \\
Understanding & $2,4,10$ \\
Mechanistic reasoning & $2,4,6,7,8,11,13$ \\
Argument skills & 2 \\
Learning strategies & $4,6,9$ \\
Nucleophiles and electrophiles & 5,12 \\
Language symbolisms & $10,13,14,15$ \\
\hline
\end{tabular}

Only two studies viewed the issues related to ORM from the perspective of the teachers as practitioners despite their critical role to provide an experiential explanation 
about a phenomenon. Practical solutions in the form of models, modules, or tools, based on the perspective of teachers as experts and practitioners in real settings, can be designed and developed. Hence, there is a need for the researchers to recognize the salient features in organic reaction mechanisms such as the wide scope of ORM contents and the dynamic nature of the reactions besides being abstract and difficult just like other scientific concepts.

Question Four: What limitations are outlined from the studies in organic reaction mechanisms reviewed?

Findings from Table 6 revealed the three limitations faced by the researchers were identified which can be attributed to the nature of organic chemistry components or topics as being cognitively difficult throughout the curriculum.

Table 6 Limitations of the Studies Reviewed Regarding ORM

\begin{tabular}{ll}
\hline Limitation & Study Number \\
\hline Nature of Subject Matter & $2,4,5,12$, \\
Sample size & 9,1315, \\
Methodology & $3,6,14$ \\
\hline
\end{tabular}

Several limitations regarding teaching and learning organic reaction mechanisms were drawn from the studies included in this scoping review shown in Table 6. ORM topics keep reoccurring at various levels with slight differences, with each encounter increasing in complexity. Thus, research on the alternative ways of approaching ORM concepts in teaching and learning is needed to provide a clear structure of the concepts with the use of symbolic language, mechanistic reasoning, visual representation, varied reaction types, and basic concepts. The limitation due to sample size will not impact the research findings if the research can show the rigour and validity of results. It undeniable that there is a need for more empirical studies on the use of hands-on, minds-on strategies that apply experimental methods to determine the most appropriate approach of teaching ORM to minimise students' common errors.

\section{Discussion}

In this section, the findings are discussed to get a conceptual understanding and provide a clear picture of the current research studies on the teaching and learning of organic reaction mechanisms. Imagine issues within the literature were highlighted to draw the attention of the scholars to critically consider the development of an alternative ORM teaching model for writing plausible and reasonable mechanisms.

To begin with, although ORM mechanisms are made up of highly abstract and conceptual concepts, students have continuously learned the concepts through rote memorisation (Othman Talib et al., 2014). For example, students have memorised the basic terms used in learning ORM such as the nucleophile and electrophile (Anzovino \& Lowery Bretz, 2015). While there are some pieces of evidence from students who have studied and grasped the principles of organic chemistry successfully, scholars have also disclosed a large number of misconceptions and errors created by students as a result of rote learning of certain basic concepts of organic chemistry, such as naming an organic compound and processes of organic reaction that are still incomprehensible (Ferguson \& Bodner, 2008; Flynn \& Featherstone, 2017).

The causes of ORM learning difficulties have been substantially identified through detailed scientific studies (Bhattacharyya, 2019; Flynn \& Featherstone, 2017; Galloway, Leung 
\& Flynn, 2018; Galloway, Leung \& Flynn, 2019; Popova \& Bretz, 2018; Webber \& Flynn, 2018; Weinrich \& Sevian, 2017). For instance, Webber and Flynn (2018) highlighted the abstract nature of the principles of organic chemistry, students ' low interest in learning organic chemistry, and students ' negative view of learning organic chemistry as the key causes of organic reaction mechanism learning difficulties. Galloway, Leung, and Flynn (2018) claimed that the fundamental concepts required to draw organic reaction mechanisms were not common to students. Ferguson and Bodner (2008) stated in their earlier research that students found it difficult to transfer the basic principles taught during the general chemistry course to the concepts implemented in the more advanced course in organic chemistry.

Students focused on memory, rules, and magic tricks to solve the difficulties of studying organic reaction mechanisms, which raised their cognitive load, resulting in errors. Sevian and Talanquer (2014) have also identified the misconceptions and cognitive capacity of students as the key causes of ORM difficulties. Anzovino and Bretz (2015) noted that organic reaction mechanisms were viewed by many students as an intricate activity that can only be memorized. Due to their highly loaded content, abstract, and complex nature, the difficulties of students studying ORM concepts are worsened.

Scholars such as Talanquer (2011) have previously researched the difficulties of studying organic reaction mechanisms, attributing it to the criteria for a three-dimensional model of thought at the macro, sub-micro, and symbolic levels. As well as the common use of new vocabulary to teach the concept (Bhattacharyya, 2019). Nevertheless, rote learning is very difficult due to the very large number of organic reactions available, so students are likely to produce incorrect ideas that precede the errors that occur in the organic reaction mechanism (Galloway, Leung \& Flynn, 2018). Earlier research by O'Dwyer and Childs (2011) shows the interpretation of challenging topics in organic chemistry by students as a result of their capacity and ability to learn the dynamics of organic reactions. Bhattacharyya (2013) commented in another similar thesis on the difficulties of teaching organic reaction when he described the large number of concepts needed for students to understand the mechanisms of organic reaction, including electronegativity, Lewis structures, electron density, electron cloud, charges, acid-base theory, electrophiles, and nucleophiles. Therefore, it is important to ensure that the methods used to teach organic reaction mechanisms are clear and focused on the willingness of students to understand them.

Results from the previous studies have indicated that there is an improvement in the learning of organic reaction mechanisms. However, some students still make errors in drawing organic reaction mechanisms as shown in Table 4. As such O'Dwyer and Childs (2015) reported that the grouping of compounds as bases and nucleophiles is incorrectly interpreted. In comparison, there is a weak correlation between the structural account, reasoning, and the energetic representation and proof of erroneous ideas on the nature of reactions and coordinate diagrams (Galloway, Leung \& Flynn, 2018, 2019; Popova \& Bretz, 2018). The common errors of students in drawing ORM have been widely documented. Grossman (2003), for instance, has called the attention of chemistry teachers to the common pitfalls and misconceptions faced by students when studying ORM. He urged teachers to pay careful attention to the warnings of common errors since they did not observe these errors and were hesitant to take an alert.

Inappropriate arrow placement and direction, arrow shortage, hyper valency, mixed media failures, and charges of conservation loss are some of the most common mistakes students make in drawing ORM (Bhattacharyya, 2013, 2019; Bodé, Deng \& Flynn, 2019; Bongers, Northoff \& Flynn, 2019; Cruz-Ramírez De Arellano \& Towns, 2014; Flynn \& 
Featherstone, 2017; Popova \& Bretz, 2018). These errors could be expensive, if not fatal, for students, parents, teachers, schools, and society at large, given the value of organic reaction processes in the fields of natural and health sciences, such as agriculture, biochemistry, polymers, food science, medicine, and pharmacy. Although chemistry teachers help students strive to prevent mistakes based on their own experiences, this can only be achieved with the mistakes noticed in their respective classrooms

How teachers handle their students ' errors are usually locally rooted and can vary across countries (Coppola \& Pontrello, 2014; Pawlak, 2013; Metcalfe, 2017). For example, students in the United States produce identical mathematical errors as Chinese students, but teachers 'responses vary dramatically between these two countries (Schleppenbach et al., 2007). Teachers in the United States were more likely to follow errors with comments or direct corrections, while Chinese teachers would ask follow-up questions to prompt the discussion of the errors among students. Inconsistent with this theoretical context, it is thought that teacher error management methods have a direct effect on a classroom's learning environment, whether or not it is error-free, and in turn, would affect the attitudes of students towards errors.

The majority of the studies included in this scoping review assessed students learning outcomes through qualitative and quantitative experimental designs using surveys questionnaires, interviews, and open-ended statements as shown in Table 2. Findings from these mixed methods reported improvement in the students' interest and attitudes towards organic reaction mechanisms concepts (Bodé, Deng \& Flynn, 2019; Othman Talib, Azraai Othman \& Tengku Putri Norishah, 2014). Students used of a variety of strategies in answering ORM task justified their answers by providing the cause-and-effect relationships between structures and functional groups (Bhattacharyya, 2013; Bongers, Northoff \& Flynn, 2019; Flynn \& Featherstone, 2017; Galloway, Leung \& Flynn, 2018, 2019) and also proposed plausible solutions using both strict and partial matching (Weinrich \& Sevian, 2017).

While raising the accomplishment, interest, and attitude of students are crucial elements of learning outcomes, it is also important to develop the mechanistic thinking and argument skills of students, such as language symbolisms and electron-pushing formalisms, which make it important to learn organic reaction mechanisms. Caspari, Kranz \& Graulich (2018) investigated the thinking of students through the prism of a mechanistic system to overcome the complexity of principles of organic chemistry. Their studies indicate that mechanistic thinking is very supportive and offers students more explicit explanations of organic reaction mechanisms. This scoping review revealed the bold need for mechanistic reasoning to be integrated into teaching the principles of organic reaction mechanisms.

\section{Conclusion}

A small sample size is one of the most significant limitations that many of the studies included in the review had pointed out (Bongers, Northoff \& Flynn, 2019; Popova \& Bretz, 2018; Webber \& Flynn, 2018). This lack of adequate sample size in researchers conducted on organic reaction mechanisms teaching and learning process limits both educators and researchers to generalize their findings. This by implication would contribute inhibition effect on the meaningful understanding of the organic reaction mechanisms. Though this scoping review acknowledged that studies on organic reaction mechanisms lead positive outcomes, there were only seven studies $(2,4,6,7,8,11,13)$ focusing on the development of students' mechanistic reasoning which is needed to explicitly understand the patterns of organic reaction. Furthermore, the causes of errors identified are systematic and procedural (Table 
5). Citing Duis (2011); Kryeziu (2015); Mayo (1996), if, errors identified are procedural, their causes can be easily identified, and hence solutions can be developed following the procedures of the errors. This review showed that there is no standard method for resolving the errors of students in drawing organic reaction mechanisms. Therefore, an alternative model, modules, techniques, and approaches for teaching organic reaction processes need to be created by both educators and researchers in the field of chemical education. So that researchers could be carried out to provide reliable data on the teaching and learning of organic reaction mechanisms for numerous variables.

\section{References}

Al-Balushi, S. M., \& Al-Hajri, S. H. (2014). Associating animations with concrete models to enhance students' comprehension of different visual representations in organic chemistry. Chemistry Education Research and Practice, 15(1), 47-58.

Anzovino, M. E., \& Lowery Bretz, S. (2015). Organic chemistry students' ideas about nucleophiles and electrophiles: The role of charges and mechanisms. Chemistry Education Research and Practice, 16(4), 797-810.

Arksey, H., \& O'Malley, L. (2005). Scoping studies: Towards a methodological framework. International Journal of Social Research Methodology: Theory and Practice, 8(1), 1932.

Ben-Zvi, R., Eylon, B.-S., \& Silberstein, J. (1987). Students' visualization of some chemical reactions. Education in Chemistry, 24, 117-120.

Bhattacharyya, G. (2013). From source to sink: Mechanistic reasoning using the electronpushing formalism. Journal of Chemical Education, 90(10), 1282-1289.

Bhattacharyya, G. (2019). Construction by De-construction. Journal of Chemical Education. 96, 1294-1297

Bodé, N. E., \& Flynn, A. B. (2016). Strategies of Successful Synthesis Solutions: Mapping, Mechanisms, and More. Journal of Chemical Education, 93(4), 593-604.

Bodé, N. E., Deng, J. M., \& Flynn, A. B. (2019). Getting Past the Rules and to the WHY: Causal Mechanistic Arguments When Judging the Plausibility of Organic Reaction Mechanisms. Journal of Chemical Education. 96, 1068-1082

Bodner, G. M. (1992). Refocusing the general chemistry curriculum. Journal of Chemical Education, 69, 186-190

Bongers, A., Northoff, G., \& Flynn, A. B. (2019). Working with mental models to learn and visualize a new reaction mechanism. Chemistry Education Research and Practice, 20(3), 554-569.

Caspari, I., Kranz, D., \& Graulich, N. (2018). Resolving the complexity of organic chemistry students' reasoning through the lens of a mechanistic framework. Chemistry Education Research and Practice. 19, 1117-1141

Chittleborough, G., \& Treagust, D. F. (2007). The modeling ability of non-major chemistry students and their understanding of the sub-microscopic level. Chemistry Education Research and Practice, 8(3), 274-292.

Coppola, B. P., \& Pontrello, J. K. (2014). Using errors to teach through a two-staged, structured review: Peer-reviewed quizzes and "what's wrong with me?" Journal of Chemical Education, 91(12), 2148-2154.

Cruz-Ramírez De Arellano, D., \& Towns, M. H. (2014). Students' understanding of alkyl halide reactions in undergraduate organic chemistry. Chemistry Education Research and Practice, 15(4), 501-515. 
Darwish, S., Abdo, H., \& AlShuwaiee, W. M. (2018). Opportunities, challenges and risks of transition into renewable energy: the case of the Arab Gulf Cooperation Council. International Energy Journal, 18(4).

Duis, J. M. (2011). Organic chemistry educators' perspectives on fundamental concepts and misconceptions: An exploratory study. Journal of Chemical Education, 88(3), 346350.

Ferguson, R., \& Bodner, G. M. (2008). Making sense of the arrow-pushing formalism among chemistry majors enrolled in organic chemistry. Chemistry Education Research and Practice, 9(2), 102-113.

Flynn, A. B., \& Featherstone, R. B. (2017). Language of mechanisms: exam analysis reveals students' strengths, strategies, and errors when using the electron-pushing formalism (curved arrows) in new reactions. Chemistry Education Research and Practice, 18(1), 64-77.

Flynn, A. B., \& Ogilvie, W. W. (2015). Mechanisms before reactions: A mechanistic approach to the organic chemistry curriculum based on patterns of electron flow. Journal of Chemical Education, 92(5), 803-810.

Galloway, K. R., Leung, M. W., \& Flynn, A. B. (2018). A Comparison of How Undergraduates, Graduate Students, and Professors Organize Organic Chemistry Reactions. Journal of Chemical Education. 95(3), 355-365

Galloway, K. R., Leung, M. W., \& Flynn, A. B. (2019). Patterns of reactions: A card sort task to investigate students' organization of organic chemistry reactions. Chemistry Education Research and Practice. 20(1), 30-52

García-Moya, I., Bunn, F., Jiménez-Iglesias, A., Paniagua, C., \& Brooks, F. M. (2019). The conceptualisation of school and teacher connectedness in adolescent research: a scoping review of the literature. Educational Review. 71(4), 423-444.

Grossman, R. B. (2003). The Art of Writing Reasonable Organic Reaction Mechanisms. Springer: New York.

Hanson, R., \& Acquah, S. (2014). Enhancing concept understanding through the use of microchemistry equipment and collaborative activities. Journal of Education and Practice, 5(12), 120-130

Johnstone, A. H. (1993). The development of chemistry teaching: A changing response to changing demand. Journal of Chemical Education, 70(9), 701-705

Kryeziu, L. (2015). Learning from Errors. ILIRIA International Review, 5(1), 391-408.

Levy, D. E. (2008). Arrow-pushing in Organic Chemistry: An Easy Approach to Understanding Reaction Mechanisms. John Wiley \& Sons: New Jersey.

Mayo, D. G. (1996). Error and the Growth of Experimental Knowledge. University of Chicago Press: Chicago

Metcalfe, J. (2017). Learning from errors. Annual Review of Psychology, 68, 465-489.

Meyer, J. H. F., \& Land, R. (2005). Threshold concepts and troublesome knowledge (2): Epistemological considerations and a conceptual framework for teaching and learning. Higher Education, 49(3), 373-388.

Moher, D., Liberati, A., Tetzlaff, J., \& Altman, D. G. (2009). PRISMA Group: Methods of systematic reviews and meta-analysis: preferred reporting items for systematic reviews and meta-analyses: the PRISMA statement. Journal of Clinical Epidemiology, 62, 1006-1012.

O'Dwyer, A., \& Childs, P. (2011). Second level Irish pupils' and teachers' view of difficulties in organic chemistry. In IOSTE Mini-Symposium. 
O'Dwyer, A., \& Childs, P. (2015). Organic Chemistry in Action! What Is the Reaction? Journal of Chemical Education, 92(7), 1159-1170.

Othman Talib, Azraai Othman, \& Tengku Putri Norishah. (2014). OCRA - Authentic mobile application for enhancing the value of mobile learning in organic chemistry. European Conference on E-Learning. Academic Conferences Limited, 527-535.

Pawlak, M. (2013). Error Correction in the Foreign Language Classroom: Reconsidering the Issues. Springer Science \& Business Media.

Popova, M., \& Bretz, S. L. (2018). "It's Only the Major Product That We Care About in Organic Chemistry": An Analysis of Students' Annotations of Reaction Coordinate Diagrams. Journal of Chemical Education, 95(7), 1086-1093.

Rasheed, S. P., Younas, A., \& Sundus, A. (2019). Self-awareness in nursing: A scoping review. Journal of Clinical Nursing, 28(5-6), 762-774.

Schleppenbach, M., Flevares, L. M., Sims, L. M., \& Perry, M. (2007). Teachers' responses to student mistakes in Chinese and US mathematics classrooms. The Elementary School Journal, 108(2), 131-147.

Sevian, H., \& Talanquer, V. (2014). Rethinking chemistry: A learning progression on chemical thinking. Chemistry Education Research and Practice. 15(1), 10-23.

Talanquer, V. (2011). Macro, sub micro, and symbolic: The many faces of the chemistry "triplet." International Journal of Science Education, 33(2), 179-195.

Tode, T. (2003). From unanalyzed chunks to rules: The learning of the English copula be by beginning Japanese learners of English. IRAL, 41(1), 23-54

Treagust, D., Chittleborough, G., \& Mamiala, T. (2003). The role of sub microscopic and symbolic representations in chemical explanations. International Journal of Science Education, 25(11), 1353-1368.

Tsaparlis, G. (2009). Learning at the macro level: The role of practical work. In Multiple Representations in Chemical Education Book Series Volume 4, 109-136. Dordrecht: Springer.

Webber, D. M., \& Flynn, A. B. (2018). How are students solving familiar and unfamiliar organic chemistry mechanism questions in a new curriculum? Journal of Chemical Education, 95(9), 1451-1467.

Weinrich, M. L., \& Sevian, H. (2017). Capturing students' abstraction while solving organic reaction mechanism problems across a semester. Chemistry Education Research and Practice, 18(1), 169-190.

Zarubica, A., Kostic, D., Rancic, S., Popovic, Z., Vasic, M., \& Radulovic, N. (2012). An improvement of the eighth-grade pupils' organic chemistry knowledge with the use of a combination of educational tools: An evaluation study - expectations and effects. New Educational Review. 30(4), 93-102 